\title{
Behaviors and Attitudes of Students towards Environmental Issues at Faculty of Agriculture in Northern Cyprus
}

\author{
Fidan Aslanova* and Abdulrahman Almoktar S Haswa \\ Atatürk Faculty of Education, Marmara University Mersin, Turkey
}

Submission: January 30, 2018; Published: July 09, 2018

*Corresponding author: Fidan Aslanova, Near East University, Atatürk Faculty of Education, Mersin 10 Turkey

\begin{abstract}
This study was conducted in order to identify the attitudes towards environment and knowledge of students of Agriculture Department of Northern Cyprus Universities about the environment. A questionnaire of four sections was conducted with university students during the research. The survey was organized as; personal information at the first section, environmental knowledge test at the second section, attitudes towards environment at the third section and behavioral scales at the fourth section. The research consisted of students studying in Agriculture Department in Northern Cyprus Universities in spring semester of 2015-2016 academic year, as the sample consisted of 114 female, 186 male, totally 300 students studying in fall semester of the same academic year. The data obtained during the application were analyzed in SPSS 20.00 package program. Whether the attitudes and behaviors' of students towards environment differed in terms of independent variables of the research were investigated by using t-test for two variable features and Anova, Wilkis Lambda, Manova test for more than two features. According to the findings of the research, the attitudes and behaviors' of university students towards environment do not differ according to educational level, income level of their parents and whether they received training about environment.
\end{abstract}

Keywords: Environment; Environmental Problems; Environmental Education; Environmental Attitudes and Behaviors; Anova; Wilkis lambda; Manova test; Socio-aesthetic values; Threatening life; Ecological consciousness; Attitude scale; Data collection; Measuring tools; T-test; Manova analysis techniques; Independent variables; Dependent variables; Anova analysis; Scheffe test; Hypothesis; Error margins

\section{Introduction}

As of the first periods of history, the fact that human being has benefited from the natural resources and the efforts to improve life conditions has shown a continuous increase and diversification in the direction of technological developments [1]. Governments all around the world make effort to make their population reach better life standards through economic growth [2]. This process has continued to our date by multiplying. 20th century is the one in which human being progressed majorly in science and technology. This breakthrough increases life standards of people, even we can see that we are beyond the dream of people lived in the previous century. It is undoubtedly the environment most affected by this development. The environment is defeated by the power fight of economy and people have not given up attacks that will destroy them [3], they have began to exhaust both themselves and the [4].

Generally, there is a susceptibility towards environmental problems both individually and socially, and this susceptibility is increasing. The fact that social values have important role in understanding of individual and social environmental issues and in their solution has been known for a long time $[5,6]$. The situa tion emerging from the structure of environmental issues causes students not to understand adequately the events causing environmental problems. The fact that environmental events are not understood accurately forms the core of environmental problems. Many researchers indicate that the root cause of environmental problems is the developing industry and increase in population rapidly [7]. For this reason, one of the main problems of this century we live in is the environmental problems. Education for environment, international cooperation in solution of environmental problems common policy and mutual collaboration among governments are accepted as a prior condition in $21^{\text {st }}$ century. Because it will not be enough to save the earth or themselves in long period and that only a few countries have achievements on this issue without making common and simultaneous environmental policies among countries; without determining common policies and sanctions that will satisfy both developed and developing countries in solution of global environmental issues; without spreading the mentality of education for environment in all countries [8]. 
Many societies particularly European Union put forward many projects and try to take precautions in order that people could live more healthy environments in today's world where several doomsday scenarios are produced [9]. Today, one of the solutions taken into consideration for protecting the environment comes environmental education. Environmental education comprises all of the society. In this regard, environmental education could be described as developing environmental awareness in all societies, providing permanent and positive behaviour changes towards environment and protecting natural, historical, cultural, socioaesthetic values, providing active participation and taking place in the solution of problems $[10,11]$. The education of protecting the nature and natural resources is the core of environmental education. The aim in environmental education is to make people not only be aware of the environment but also make them volunteer participants by increasing their abilities on environment issue [12]. The negative way of the specialization of students in a certain field at higher education is that they become stranger to the perception of any social problem taken by the society. Accordingly, well-educated students will fulfill a certain task, however; they will go away from abilities and talents of solving complicated problems that society faces [13]. Especially, in order to have success in studies of solving environmental problems the importance of tending primarily to education among disciplines as well as special fields at higher education [14].

That environmental issues are globalized and they have come a status of threatening life on earth have caused people to question again their attitudes and behaviours towards environment and their relationship with nature; to re-observe their duties and responsibilities against nature; to re-define the ecologic culture and environmental consciousness. Particularly, the relationship between education and environmental problems has started to be investigated lately and to question the suitability of curriculum of schools with the environment sensitivity and ecological consciousness. As a result of all these issues, the necessity, importance of environmental education and making its awareness among students in schools have become a matter on the agenda both in our country and all around the world. The aim of this study is to research whether there is any difference among the attitudes and behaviours of university students of Agriculture Department in Northern Cyprus Universities towards environment.

\section{Method}

\section{Research model}

In this research, it is investigated whether the environmental attitudes and behaviours of Libyan, Turkish and Nigerian students who are studying at Agriculture Department of Northern Cyprus Universities in terms of various variables. For this purpose, the study was carried out with relational screening model. The relational screening models are the research models that intend to determine the presence and/or degree of covariance between or among two or more variables. The variables that will be sought for a relation are symbolized, but this symbolization should be done in such a way to allow for a relational analysis. The current situations and conditions are exactly put forth in scanning models. In this research, as dependent variable "Environmental Knowledge Test", "Attitude Scale towards Environment", "Behavior Scale towards Environment" were used.

\section{The universe and sample}

The research consisted of students studying in Agriculture Department in Northern Cyprus Universities in spring semester of 2015-2016 academic year. The research exemplary consisted of 114 female, 186 male, totally 300 students studying in fall semester of the same academic year. The number of students forming the exemplary of the research according to their sex is given in Table 1.

Table 1: Distribution table of students forming the examplary according to their sex.

\begin{tabular}{|c|c|}
\hline Sex & Number of Students \\
\hline Female & 114 \\
\hline Male & 186 \\
\hline Total & 300 \\
\hline
\end{tabular}

\section{Data collection technique}

The following phases were followed with reference to data collection needed for the research: the researches made regarding the matter and related literature scanning firstly, and the surveys applied in these researches were examined. Later, a questionnaire was determined in the direction of the objective of the research. The questionnaire was planned in 3 sections. The following data collection tools were used in the research:

I. Personal Information Form

II. Environmental Knowledge Test

III. Attitude and Behaviour Scale towards Environment.

\section{Data collection process}

In order to realize the scanning dimension of the research, the scales to be used as measuring tools were prepared first. The questionnaire was applied on the students studying at Agriculture faculty of Northern Cyprus that was predetermined. The application was realized within the hours the students were available in fall semester of 2015-2016 academic year. All of the applications were conducted by the researcher himself. At the beginning of the application, some explanations were made to the students regarding how to fill in the related sections and the structure of the survey, and their questions were answered during the application.

\section{Analysis of data}

The data was analyzed by using SPSS-20 (Statistical Package for the Social Sciences) package program. In the analysis of data the t-test, Anova, Scheffe, Wilkis Lambda and Manova analysis techniques were used as well as the investigation of the statistics.

Manova analysis: In case that two independent variables influence multi dependent variables, Two-Way MANOVA is used. 
It is used to research the common effect of multi independent variables on multi dependent variables (wilks lambda) [15].

Anova analysis: It is used to analyze how ANOVA independent variables interact among themselves and the effects of such interaction on dependent variable. In case that the variable to be analyzed has more than 2 groups, the method to be used is Anova. In order to investigate whether there is any difference of any group based on Anova analysis; if data shows a normal distribution the subtests like Turkey, LSD or Sheffe are used. In this study Scheffe test was preferred.

Scheffe test: Scheffe method was developed to compare all linear combinations that are possible among groups; this method in general terms is handled as post hoc type which does not care about the hypothesis that observation numbers in groups should be equal and which keeps under control the $\alpha$ error margin (conservative) in case that the numbers to be compared and that are the most flexible are many $[16,17]$.

Frequency test: It presents the data as numbers and percentages in order to describe the characteristics of the distribution of the scores or values belonging to one or more variable(s).

\section{Validity and reliability}

Table 2: Reliability of behavioral scale.

\begin{tabular}{|c|c|}
\hline \multicolumn{2}{|c|}{ Reliability Statistics } \\
\hline Cronbach's Alpha & N of Items \\
\hline 852 & 17 \\
\hline
\end{tabular}

The researcher is focused on the reliability and validity of research method in this section. The reliability of a scale is about the random errors in the scales that were prepared by the researcher. The data obtained with help of a not reliable scale has no contribution to the research. Because when the same test is applied to the same people in different times and the results are seen to be different, it won't be possible to interpreted on the results obtained. The valid basic percentages are given in Table 2 regarding the validity and reliability of the behavioral scale giving the data. Cronbach Alpha coefficient of the behavioral scale has been found to be, 852 . The valid basic percentages are given in Table 3 regarding the validity and reliability of the attitude scale giving the data. Cronbach Alpha coefficient of the attitude scale has been found to be, 829 .

Table 3: Reliability of behavioral scale.

\begin{tabular}{|c|c|}
\hline \multicolumn{2}{|c|}{ Reliability Statistics } \\
\hline Cronbach's Alpha & N of Items \\
\hline 829 & 21 \\
\hline
\end{tabular}

\section{Findings and comments}

What levels are the environmental attitudes of Libyan, Turkish and Nigerian students who are studying at Agriculture Department of Northern Cyprus Universities? As it can be seen in Table 3, a significant difference was found in attitudes of Libya and Nigeria students studying in Agriculture department of Northern Cyprus universities towards environment $(p=, 044)$. When such difference is investigated by Scheffe test, it can be seen that Nigerian students have higher attitudes towards the environment ( $\bar{X}=59,20$ ) when compared to Libyan students $(\bar{X}=55,58)$. What levels are the environmental behaviours of Libyan, Turkish and Nigerian students who are studying at Agriculture Department of Northern Cyprus Universities? As it can be seen in Table 4, no significant difference was found in attitudes of TR, Libya and Nigeria students studying in Agriculture department of Northern Cyprus universities towards environment $(p=, 056)$.

Table 4: Anova test of attitude level of libya, turkish and nigerian students.

\begin{tabular}{|c|c|c|c|}
\hline Attitude & Sum of Squares & df & Mean Square \\
\hline Between Groups & $8,65,624$ & 2 & $4,32,812$ \\
\hline Within Groups & $4,07,87,293$ & 297 & $1,37,331$ \\
\hline Total & $4,16,52,917$ & 299 & \\
\hline
\end{tabular}

Do the environmental attitudes and behaviours of Libyan, Turkish and Nigerian students who are studying at Agriculture Department of Northern Cyprus Universities differ based on sex. As it can be seen in Table 5, the common effect was not found to be significant between the genders of Turkish, Libyan and Nigerian students as well as the attitudes and behaviours of students studying in Agriculture faculty of Northern Cyprus universities towards environment [wilkis lambda $\wedge=, 985, \mathrm{~F}=1,149, \mathrm{p}>, 05]$ ]. However, it was found that attitudes of students have a significant Table 5: Anova test of behaviour level of libya, turkish and nigerian students.

\begin{tabular}{|c|c|c|c|c|c|c|c|}
\hline Behavior & Sum of Squares & df & Mean Square & f & p & Description & \\
\cline { 1 - 4 } Between Groups & $1,72,574$ & 2 & 86,287 & & & \multirow{2}{*}{ Difference } \\
\cline { 1 - 4 } Within Groups & $4,46,50,093$ & 297 & $1,50,337$ & \multirow{2}{*}{0,574} & 564 & No & N.05 \\
\hline Total & $4,48,22,667$ & 299 & & & & \\
\hline
\end{tabular}




\section{Biostatistics and Biometrics Open Access Journal}

Table 6: Manova test of the relationship between attitude and behaviour levels towards environment and sex variable.

\begin{tabular}{|c|c|c|c|c|c|c|c|}
\hline Source & Variable & Sum of Squares & sd & Mean Square & f & $\mathbf{p}$ & Description \\
\hline \multirow{2}{*}{ Gender } & Attitude & $9,04,284$ & 1 & $9,04,284$ & 6,681 & 0.10 & $\mathrm{p}<.05$ \\
\hline & Behaviour & $2,36,320$ & 1 & $2,36,320$ & 1,566 & 212 & $p>.05$ \\
\hline \multirow{2}{*}{ Nationality } & Attitude & $9,66,770$ & 2 & $4,83,385$ & 3,571 & 29 & $\mathrm{p}<.05$ \\
\hline & Behaviour & $2,93,787$ & 2 & $1,46,894$ & 973 & 379 & $p>.05$ \\
\hline \multirow{2}{*}{$\mathrm{YxC}$} & Attitude & $5,43,096$ & 2 & $2,71,548$ & 2,006 & 136 & $p>.05$ \\
\hline & Behaviour & $1,04,626$ & 2 & 52,313 & 347 & 707 & $p>.05$ \\
\hline \multirow{2}{*}{ Error } & Attitude & $3,97,96,046$ & 294 & $1,35,361$ & & & \\
\hline & Behaviour & $4,43,64,503$ & 294 & $1,50,900$ & & & \\
\hline \multirow[t]{2}{*}{ Correct Table } & Attitude & $4,16,52,917$ & 299 & & & & \\
\hline & Behaviour & $4,48,22,667$ & 299 & & & & \\
\hline
\end{tabular}

[wilkis lambda $\wedge=, 985, F=1,149, p=333(p>, 05)$ ]

Table 7: manova test of the relationship between attitude and behaviour levels towards environment and father's educational background.

\begin{tabular}{|c|c|c|c|c|c|c|c|}
\hline Source & Variable & Sum of Squares & sd & Mean Square & f & $\mathbf{p}$ & Description \\
\hline \multirow{2}{*}{$\begin{array}{l}\text { Father } \\
\text { education }\end{array}$} & Attitude & $5,89,441$ & 5 & $1,17,888$ & ,860 &, 509 & $\mathrm{p}>.05$ \\
\hline & Behaviour & $5,83,186$ & 5 & $1,16,637$ &, 792 & ,556 & $\mathrm{p}>.05$ \\
\hline \multirow{2}{*}{ Nationality } & Attitude & $3,48,321$ & 2 & $1,74,160$ & 1,270 & ,282 & $\mathrm{p}>.05$ \\
\hline & Behaviour & 48,454 & 2 & 24,227 & , 165 & ,848 & $\mathrm{p}>.05$ \\
\hline \multirow{2}{*}{ YxC } & Attitude & $16,80,465$ & 10 & $1,68,047$ & 1,225 & 274 & $\mathrm{p}>.05$ \\
\hline & Behaviour & $22,23,355$ & 10 & $2,22,336$ & 1,510 & ,135 & $\mathrm{p}>.05$ \\
\hline \multirow{2}{*}{ Error } & Attitude & $3,86,73,247$ & 282 & $1,37,139$ & & & \\
\hline & Behaviour & $4,15,24,724$ & 282 & $1,47,251$ & & & \\
\hline \multirow{2}{*}{ Correct Table } & Attitude & $4,16,52,917$ & 299 & & & & \\
\hline & Behaviour & $4,48,22,667$ & 299 & & & & \\
\hline
\end{tabular}

[wilkis lambda $\wedge=, 917, F=1,247, p=, 210(p>, 05)$ ]

Table 8: Manova test of the relationship between attitude and behaviour levels towards environment and mother's educational background.

\begin{tabular}{|c|c|c|c|c|c|c|c|}
\hline Source & Variable & Sum of Squares & sd & Mean Square & f & $\mathbf{p}$ & Description \\
\hline \multirow{2}{*}{ Mother Education } & Attitude & $11,97,466$ & 5 & $2,39,493$ & 1,812 & 110 & $\mathrm{p}>.05$ \\
\hline & Behaviour & $2,07,157$ & 5 & 41,431 &, 280 & ,924 & $p>.05$ \\
\hline \multirow{2}{*}{ Nationality } & Attitude & $5,08,440$ & 2 & $2,54,220$ & 1,923 & 148 & $\mathrm{p}>.05$ \\
\hline & Behaviour & $1,70,471$ & 2 & 85,236 &, 576 &, 563 & $p>.05$ \\
\hline \multirow{2}{*}{ YxC } & Attitude & $24,11,351$ & 10 & $2,41,135$ & 1,824 & ,056 & $\mathrm{p}>.05$ \\
\hline & Behaviour & $20,20,198$ & 10 & $2,02,020$ & 1,366 & 196 & $\mathrm{p}>.05$ \\
\hline \multirow{2}{*}{ Error } & Attitude & $3,72,72,046$ & 282 & $1,32,170$ & & & \\
\hline & Behaviour & $4,17,17,273$ & 282 & $1,47,934$ & & & \\
\hline \multirow{2}{*}{ Correct Table } & Attitude & $4,16,52,917$ & 299 & & & & \\
\hline & Behaviour & $4,48,22,667$ & 299 & & & & \\
\hline
\end{tabular}

[wilkis lambda $\wedge=, 889, F=1,556, p=, 058(p>, 05)$ ]

Do the environmental attitudes and behaviours of Libyan, Turkish and Nigerian students who are studying at Agriculture Department of Northern Cyprus Universities differ based on educational background of their parents. As it can be seen in Table 6 , the common effect was not found to be significant between the educational backgroung of fathers of Turkish, Libyan and Nigerian students as well as the attitudes and behaviours of students studying in Agriculture faculty of Northern Cyprus universities towards environment [wilkis lambda $\wedge=, 917, \mathrm{~F}=1,270, \mathrm{p}=, 210$ (p>05)] (Table 7-15). Again when Table 15 is examined, it was not found a significant variation between the educational background and attitudes of all students' fathers ( $\mathrm{p}=.509 \mathrm{p}>.05)$ and behaviours ( $p=.556 p>.05)$. Based on such findings, it is obvious that there is no significant relationship and variation between their own attitudes and behaviours of Turkish, Libyan and Nigerian students according to their fathers' educational background. As it can be seen in Table 7, the common effect was not found to be significant between the educational backgroung 


\section{Biostatistics and Biometrics Open Access Journal}

of mothers of Turkish, Libyan and Nigerian students as well as the attitudes and behaviours of students studying in Agriculture faculty of Northern Cyprus universities towards environment [wilkis lambda $\wedge=.889, \mathrm{~F}=1.2556, \mathrm{p}=.0,58(\mathrm{p}>, 05)]$. Again when Table 5 is examined, it was not found a significant variation between the educational background and attitudes of all students' Table 9: Manova test of the relationship between attitude and behaviour levels towards environment and family incomes.

\begin{tabular}{|c|c|c|c|c|c|c|c|}
\hline Source & Variable & Sum of Squares & sd & Mean Square & $\mathbf{f}$ & $\mathbf{p}$ & Description \\
\hline \multirow{2}{*}{ Salary } & Attitude & $13,30,764$ & 4 & $3,32,691$ & 2,450 & 046 & $\mathrm{p}>.05$ \\
\hline & Behaviour & $2,25,710$ & 4 & 56,428 & ,373 & ,828 & $\mathrm{p}>.05$ \\
\hline \multirow{2}{*}{ Nationality } & Attitude & $6,68,073$ & 2 & $3,34,037$ & 2,459 & ,087 & $p>.05$ \\
\hline & Behaviour & $2,66,657$ & 2 & $1,33,328$ & ,880 & ,416 & $\mathrm{p}>.05$ \\
\hline \multirow{2}{*}{$\mathrm{YxC}$} & Attitude & $11,84,092$ & 8 & $1,48,011$ & 1,090 & ,370 & $\mathrm{p}>.05$ \\
\hline & Behaviour & $11,36,844$ & 8 & $1,42,106$ & ,938 & ,485 & $\mathrm{p}>.05$ \\
\hline \multirow{2}{*}{ Error } & Attitude & $11,84,092$ & 8 & $1,48,011$ & & & \\
\hline & Behaviour & $11,36,844$ & 8 & $1,42,106$ & & & \\
\hline \multirow{2}{*}{ Correct Table } & Attitude & $4,16,52,917$ & 299 & & & & \\
\hline & Behaviour & $4,48,22,667$ & 299 & & & & \\
\hline
\end{tabular}

[wilkis lambda $\wedge=, 953, F=, 868, p=, 606(p>, 05)$ ]

Table 10: Manova test of the relationship between attitude and behaviour levels towards environment and whether to have received environmental course.

\begin{tabular}{|c|c|c|c|c|c|c|c|}
\hline Source & Variable & Sum of Squares & sd & Mean Square & f & p & Description \\
\hline \multirow{2}{*}{ Course } & Attitude & 66,691 & 1 & 66,691 & ,487 & ,486 & $p>.05$ \\
\hline & Behaviour & $3,70,813$ & 1 & $3,70,813$ & 2,501 & 115 & $p>.05$ \\
\hline \multirow{2}{*}{ Nationality } & Attitude & $3,05,329$ & 2 & $1,52,664$ & 1,114 & ,330 & $\mathrm{p}>.05$ \\
\hline & Behaviour & $1,57,507$ & 2 & 78,754 &, 531 & ,588 & $\mathrm{p}>.05$ \\
\hline \multirow{2}{*}{ YxC } & Attitude & $2,13,595$ & 2 & $1,06,798$ &, 779 & ,460 & $\mathrm{p}>.05$ \\
\hline & Behaviour & $2,11,446$ & 2 & $1,05,723$ &, 713 & ,491 & $\mathrm{p}>.05$ \\
\hline \multirow{2}{*}{ Error } & Attitude & $4,02,97,909$ & 294 & $1,37,068$ & & & \\
\hline & Behaviour & $4,35,91,731$ & 294 & $1,48,271$ & & & \\
\hline \multirow{2}{*}{ Correct Table } & Attitude & $4,16,52,917$ & 299 & & & & \\
\hline & Behaviour & $4,48,22,667$ & 299 & & & & \\
\hline
\end{tabular}

Table 11: Manova test of the relationship between attitude and behaviour levels towards environment and whether to be a member of environmental organization.

\begin{tabular}{|c|c|c|c|c|c|c|c|}
\hline Source & Variable & Sum of Squares & sd & Mean Square & f & $\mathbf{p}$ & Description \\
\hline \multirow{2}{*}{ Membership of NGO } & Attitude & $1,30,310$ & 1 & $1,30,310$ & 947 & ,331 & $\mathrm{p}>.05$ \\
\hline & Behaviour & 61,804 & 1 & 61,804 & ,408 &, 523 & $\mathrm{p}>.05$ \\
\hline \multirow{2}{*}{ Nationality } & Attitude & $2,50,034$ & 2 & $1,25,017$ & 909 & ,404 & $\mathrm{p}>.05$ \\
\hline & Behaviour & 48,806 & 2 & 24,403 & 161 & 851 & $\mathrm{p}>.05$ \\
\hline \multirow{2}{*}{$\mathrm{YxC}$} & Attitude & $2,93,035$ & 2 & $1,46,518$ & 1,065 & 346 & $\mathrm{p}>.05$ \\
\hline & Behaviour & $1,12,585$ & 2 & 56,293 & ,372 & 690 & $\mathrm{p}>.05$ \\
\hline \multirow{2}{*}{ Error } & Attitude & $4,04,35,472$ & 294 & $1,37,536$ & & & \\
\hline & Behaviour & $4,45,13,537$ & 294 & $1,51,407$ & & & \\
\hline \multirow{2}{*}{ Correct Table } & Attitude & $4,16,52,917$ & 299 & & & & \\
\hline & Behaviour & $4,48,22,667$ & 299 & & & & \\
\hline
\end{tabular}

[wilkis lambda $\wedge=, 991, F=, 638, p=, 636(p>, 05)$ ] NGO: None govermental organization

Do the environmental attitudes and behaviours of Libyan, Turkish and Nigerian students who are studying at Agriculture Department of Northern Cyprus Universities differ based on

economic status of their parents. As it can be seen in Table 8, the common effect was not found to be significant among the families' monthly income levels of Turkish, Libyan and Nigerian students 


\section{Biostatistics and Biometrics Open Access Journal}

as well as the attitudes and behaviours of students studying in Agriculture faculty of Northern Cyprus universities towards environment [wilkis lambda $\wedge=, 953, F=, 868, p=, 606(p>, 05)$ ] (Table 9-16). Again when Table 17 is examined, while there was generally a significant variation between family income levels and attitudes of all students $(p=, 46 p>, 05)$, no significant variation was found to among their behaviours. As a result of the Tukey HSD test which was made to find between what groups that difference was relating to the attitudes, it was observed that there is variation between TR, Libyan and Nigerian students who have an income between 1000 and 2000TL, and TR, Libyan and Nigerian students who have income between 2000 and 3000TL. When the distribution of this variation is examined according to income level, it was concluded that Nigerian students who have an income between 1000 and $2000(\overline{\mathrm{X}}=58,82)$, Libyan students $(\bar{X}=53,67)$ and TR students $(\bar{X}=47,50)$ have lower attitudes than those who have income levels between 2000 and 3000 for Nigerian $(\bar{X}$ =60,59), Libyan, ( $\bar{X}=59,77)$ and TR $(\bar{X}=60,67)$ students. Based on such results, it is obvious that as income level increases, the attitudes of both TR, Libyan and Nigerian students increase too.

Table12: Table of Average Environmental Knowledge Test.

\begin{tabular}{|c|c|c|c|c|c|c|}
\hline $\mathbf{N}$ & Range & Minimum & $\begin{array}{c}\text { Maxi- } \\
\text { mum }\end{array}$ & Mean & \multicolumn{2}{|c|}{ Std. Deviation } \\
\hline $\begin{array}{c}\text { Knowl- } \\
\text { edge }\end{array}$ & 300 & 15,00 & 3,00 & 18,00 & $1,05,700$ & $3,23,625$ \\
\hline Total & \multicolumn{5}{|c|}{300} \\
\hline
\end{tabular}

Table13: Which one of the following are not the result of air pollution.

\begin{tabular}{|c|c|c|c|}
\hline \multirow{3}{*}{ Valid } & & Frequency & Percent \\
\cline { 2 - 4 } & False & 121 & 40,3 \\
\hline \multirow{2}{*}{} & True & 179 & 59,7 \\
\hline
\end{tabular}

Table14: Which of the followings can be done to reduce air pollution.

\begin{tabular}{|c|c|c|c|}
\hline \multirow{2}{*}{ Valid } & \multicolumn{2}{|c|}{ Frequency } & Percent \\
\hline & False & 135 & 34,3 \\
\cline { 2 - 4 } & True & 165 & 65,7 \\
\hline \multirow{2}{*}{} & Total & 300 & 100,0 \\
\hline
\end{tabular}

Table 15: Which of the ideas of promoting the use of bicycles to reduce direct and indirect reduce the environmental problems.

\begin{tabular}{|c|c|c|c|}
\hline \multirow{2}{*}{ Valid } & \multicolumn{2}{|c|}{ Frequency } & Percent \\
\hline & False & 145 & 48,3 \\
\cline { 2 - 4 } & True & 155 & 51,7 \\
\hline & Total & 300 & 100,0 \\
\hline
\end{tabular}

Table 16: Which of the Following Will Not Be Considered as One of the Causes of Air Pollution?.

\begin{tabular}{|l|c|c|c|}
\hline \multirow{2}{*}{ Valid } & \multicolumn{2}{|c|}{ Frequency } & Percent \\
\hline & False & 76 & 25,3 \\
\cline { 2 - 4 } & True & 224 & 74,7 \\
\hline \multirow{2}{*}{} & Total & 300 & 100,0 \\
\hline
\end{tabular}

Table 17: Which of the Following or Which Are the Result of Amount of $\mathrm{CO}_{2}, \mathrm{CH}_{4}$ and $\mathrm{O}_{\mathrm{s}}$ Gas Increases in the Atmosphere.

\begin{tabular}{|c|c|c|c|}
\hline \multirow{2}{*}{ Valid } & \multicolumn{2}{|c|}{ Frequency } & Percent \\
\hline & False & 76 & 25,3 \\
\cline { 2 - 4 } & True & 224 & 74,7 \\
\hline & Total & 300 & 100,0 \\
\hline
\end{tabular}

Table 18: Which of the Following Can Not Be Represented as One of the Causes for Acid Rain.

\begin{tabular}{|c|c|c|c|}
\hline \multirow{2}{*}{ Valid } & \multicolumn{2}{|c|}{ Frequency } & Percent \\
\hline & False & 76 & 25,3 \\
\cline { 2 - 4 } & True & 224 & 74,7 \\
\hline & Total & 300 & 100,0 \\
\hline
\end{tabular}

Do the environmental attitudes and behaviours of Libyan, Turkish and Nigerian students who are studying at Agriculture Department of Northern Cyprus Universities differ based on whether they have received environmental course. As it can be seen in Table 9, the common effect was not found to be significant between whether Turkish, Libyan and Nigerian students have received courses about the environment before as well as the attitudes and behaviours of students studying in Agriculture faculty of Northern Cyprus universities towards environment [wilkis lambda $\wedge=, 993, F=, 513, p=, 726(p>, 05)$ ]. Again when Table 18 is examined, there was not found generally any significant variation between whether the students have received courses about the environment before and their attitudes ( $p=, 486$ , $p>, 05)$ and behaviours $(p=, 115, p>, 05)$. Based on such findings, it is obvious that there is no significant relationship and variation between their own attitudes and behaviours of Turkish, Libyan and Nigerian students according to whether the students have received courses about the environment before.

Table 19: Which one or which ones of the followings is (are) the result of the greenhouse effect.

\begin{tabular}{|c|c|c|c|}
\hline \multirow{2}{*}{ Valid } & \multicolumn{2}{|c|}{ Frequency } & Percent \\
\hline & False & 216 & 72,0 \\
\cline { 2 - 4 } & True & 84 & 28,0 \\
\hline & Total & 300 & 100,0 \\
\hline
\end{tabular}

Do the environmental attitudes and behaviours of Libyan, Turkish and Nigerian students who are studying at Agriculture Department of Northern Cyprus Universities differ based on whether they are a volunteer member of any organization about the environment. As it can be seen in Table 10, the common effect was not found to be significant between whether Turkish, Libyan and Nigerian students are a member of any organization about the environment as well as the attitudes and behaviours of students studying in Agriculture faculty of Northern Cyprus universities towards environment [wilkis lambda $\wedge=, 991, F=, 638, p=, 636$ ( $p>, 05)]$. Again when Table 19 is examined, there was not found generally any significant variation between whether the students are a member of any organization about the environment and their attitudes $(p=, 331, p>, 05)$ and behaviours $(p=, 523, p>, 05)$. 
Based on such findings, it is obvious that there is no significant relationship and variation between their own attitudes and behaviours of Turkish, Libyan and Nigerian students according to whether the students are a member of any organization about the environment.

Table 20: The use of pesticides is effective as a priority to which ever of the following forms of pollution.

\begin{tabular}{|c|c|c|c|}
\hline \multirow{2}{*}{ Valid } & \multicolumn{2}{|c|}{ Frequency } & Percent \\
\hline & False & 115 & 38,3 \\
\cline { 2 - 4 } & True & 185 & 61,7 \\
\hline & Total & 300 & 100,0 \\
\hline
\end{tabular}

\section{Results of knowledge test}

In this chapter of the research, the findings and comments with regard to knowledge test questions of the research are included. As it can be seen in Table 11, the maximum score that could be taken from the participants as a result of environmental knowledge test is 18,00 . The score average of the participants taken from the knowledge test seems to be 10,57. Taking into consideration this result, it can be seen that environmental consciousness of participants is average. The frequency distribution of the right and wrong answers given by the participants for each question is given as follows.

Considering the answers in Table 12 for the question "Which One of The Followings Are Not the Result of Air Pollution?" given by the students who formed the exemplary, we can see it is answered as \%40,3 "wrong" while \%59,7 "true" . Considering the answers in Table 13 for the question "Which of the Followings Can Be Done to Reduce Air Pollution?" given by the students who formed the exemplary, we can see it is answered as \%34,3 "wrong" while \%65,7"true" . Considering the answers in Table 14 for the question "Which of the Idea of Promoting the Use of Bicycles to Reduce Direct and Indirect Reduce the Environmental Problems?" given by the students who formed the exemplary, we can see it is answered as \%48,3 "wrong" while \%51,7 "true" . Considering the answers in Table 15 for the question "Which of the Following Will Not Be Considered as One of the Causes of Air Pollution?" given by the students who formed the exemplary, we can see it is answered as \%25,3 "wrong" while \%74,7 "true" . Considering the answers in Table 16 for the question "Which of the Following or Which Are the Result of Amount of $\mathrm{CO}_{2}, \mathrm{CH}_{4}$ And 03 Gas Increases in the Atmosphere?" given by the students who formed the exemplary, we can see it is answered as \%59 "wrong" while \%41"true".

Considering the answers in Table 17 for the question "Which of the Following Can Not Be Represented as One of the Causes for Acid Rain?" given by the students who formed the exemplary, we can see it is answered as \%52 "wrong" while \%48"true". Considering the answers in Table 18 for the question "Which One or Which Ones of the Following is (are) the Result of the Greenhouse Effect?" given by the students who formed the exemplary, we can see it is answered as \%28“wrong" while \%72"true". Considering the answers in Table 19 for the question "The Use of Pesticides is Effective as a Priority to Which Ever of the Following Forms of Pollution" given by the students who formed the exemplary, we can see it is answered as \%61,7"true" while \%38,3"wrong". Considering the answers in Table 20 for the question "Which of the Following Items We Use in Our Daily Basis Does Not Use CFC Gas?" given by the students who formed the exemplary, we can see it is answered as \%73,3 "wrong" while "true" \%26,7.

Table 21: Which of the following items we use in our daily basis does not use CFC gas.

\begin{tabular}{|c|c|c|c|}
\hline \multirow{2}{*}{ Valid } & \multicolumn{2}{|c|}{ Frequency } & Percent \\
\hline & False & 115 & 38,3 \\
\cline { 2 - 4 } & True & 185 & 61,7 \\
\hline & Total & 300 & 100,0 \\
\hline
\end{tabular}

We can see in Table 21 that only 6 of the questions asked are correct considering the answers given by the students for the environmental knowledge questions. Based on this result, we can say that students do not have enough knowledge about the environment.

Table 22: Distribution of the answers of students to the questions regarding environment.

\begin{tabular}{|c|c|c|c|}
\hline Questions & Answers & Number of Students & Percent (\%) \\
\hline Which One of The Following Are Not The Result of Air Pollution? & TRUE & 179 & 59,7 \\
\hline Which of the Followings Can Be Done to Reduce Air Pollution? & TRUE & 165 & 65,7 \\
\hline Which of the Following Will Not Be Considered as One of the Causes of Air Pollution? & TRUE & 224 & 74,7 \\
\hline $\begin{array}{l}\text { Which of the Following or Which Are the Result of Amount of CO2, } \mathrm{CH} 4 \text { and } 03 \text { Gas } \\
\text { Increases in the Atmosphere? }\end{array}$ & FALSE & 177 & 59,0 \\
\hline Which of the Following Can Not Be Represented as One of the Causes for Acid Rain? & FALSE & 156 & 52,0 \\
\hline Which One or Which Ones of the Followings is (are) the Result of the Greenhouse Effect? & FALSE & 216 & 72,0 \\
\hline $\begin{array}{l}\text { The Use of Pesticides is Effective as a Priority to Which Ever of The Following Forms of } \\
\text { Pollution? }\end{array}$ & TRUE & 185 & 61,7 \\
\hline Which of the Following Items We Use in Our Daily Basis Does Not Use CFC Gas? & FALSE & 220 & 73,3 \\
\hline Which of the Following or Which are Known as Greenhouse Gases? & FALSE & 231 & 77,0 \\
\hline What Do We Understand by Cfcs (Chlorofluorocarbon)? & TRUE & 155 & 51,7 \\
\hline Which of the Followings are Not Considered as Soil Pollutants? & TRUE & 185 & 61,7 \\
\hline
\end{tabular}




\section{Biostatistics and Biometrics Open Access Journal}

\begin{tabular}{|c|c|c|c|}
\hline Which of the Followings is Not a Way to Prevent Soil Pollution? & FALSE & 257 & 85,7 \\
\hline $\begin{array}{l}\text { Which is or Which are Being Mixed in the Air After We Start Our Car in the Morning in } \\
\text { Our Garage? }\end{array}$ & FALSE & 237 & 79,0 \\
\hline $\begin{array}{l}\text { Which of the Followings or Which are Considered as the Factors Which Cause Water } \\
\text { Pollution? }\end{array}$ & FALSE & 210 & 70,0 \\
\hline $\begin{array}{l}\text { Which of the Following Behaviours May Pollute the Water Which You Drink or You Use } \\
\text { to Do at Home That You Live in? }\end{array}$ & FALSE & 220 & 73,3 \\
\hline Which of The Following Is Not The Alternative Energy Sources? & FALSE & 194 & 64,7 \\
\hline $\begin{array}{c}\text { Which of The Following Which Are or May Be The Measures That Can Be Taken To } \\
\text { Prevent Noise Pollution In The Surrounding Area? }\end{array}$ & FALSE & 272 & 90,7 \\
\hline $\begin{array}{c}\text { Which of The Following Material Property Can Not Be Disposed In The Glass Piggy } \\
\text { Banks? }\end{array}$ & FALSE & 212 & 70,7 \\
\hline $\begin{array}{l}\text { Which of The Following Natural Energy Source Dose Not Contain Sulfur Component } \\
\text { Gases? }\end{array}$ & FALSE & 273 & 91,0 \\
\hline Which of The Following or Which Are Be raw To Biomass Energy? & FALSE & 187 & 62,3 \\
\hline Which of The Following Statements Best Describes The Formation of Acid Rain? & FALSE & 274 & 91,3 \\
\hline Which of The Following or Which Are, Can Be An Alternative Energy Sources? & FALSE & 225 & 75,0 \\
\hline
\end{tabular}

\section{Results}

When the results are investigated, a significant difference was found in attitudes of Libya and Nigeria students studying in Agriculture department of Northern Cyprus universities towards environment $(p=, 044)$. When such difference is investigated by Scheffe test, it can be seen that Nigerian students have higher attitudes towards the environment $(\bar{X}=59,20)$ when compared to Libyan students $(\bar{X}=55,58)$. No significant difference was found in attitudes of TR, Libya and Nigeria students towards environment $(\mathrm{p}=, 056)$. Karacaoğl [18] obtained similar results in the study he conducted on university students. The common effect was not found to be significant between the genders of Turkish, Libyan and Nigerian students as well as the attitudes and behaviours of students studying in Agriculture faculty of Northern Cyprus universities towards environment [wilkis lambda $\wedge=, 985$, $\mathrm{F}=1,149, \mathrm{p}>, 05]$. However, it was found that attitudes of students have a significant difference according to students' genders $(p=, 010, p<, 05)$. But there is no difference in their behaviours $(p=, 212, p>, 05)$. As a result of the Tukey HSD test which was made to find between what groups that difference was, it was observed that there is variation between Libyan and Nigerian students. When the distribution of this variation is examined according to sex, it was observed that the Libyan female students $(\bar{X}=56,24)$ and male students $(\bar{X}=54,77)$ have lower attitudes than Nigerian female students ( $\bar{X}=60,37)$ and male students $(\bar{X}=58,83)$. The result of the joint study of Gündüz Ş \& Aslanova F [19], Makki [20], Teyfur [21] shows parallelism with the result of the research.

The common effect was not found to be significant between the educational backgroung of fathers of Turkish, Libyan and Nigerian students as well as the attitudes and behaviours of students studying in Agriculture faculty of Northern Cyprus universities towards environment [wilkis lambda $\wedge=, 917, \mathrm{~F}=1,270, \mathrm{p}=, 210$ $(p>05)]$. Again when Table 15 is examined, it was not found a significant variation between the educational background and attitudes of all students' fathers $(p=, 509 p>, 05)$ and behaviours $(p=, 556 p>, 05)$. Based on such findings, it is obvious that there is no significant relationship and variation between their own attitudes and behaviours of Turkish, Libyan and Nigerian students according to their fathers' educational background. The common effect was not found to be significant between the educational background of mothers of Turkish, Libyan and Nigerian students as well as the attitudes and behaviours of students studying in Agriculture faculty of Northern Cyprus universities towards environment [wilkis lambda $\wedge=, 889, \mathrm{~F}=1,2556, \mathrm{p}=, 0,58(\mathrm{p}>, 05)$ ]. Again when Table 5 is examined, it was not found a significant variation between the educational background and attitudes of all students' fathers $(p=, 110 p>, 05)$ and behaviours $(p=, 924 p>, 05)$. Based on such findings, it is obvious that there is no significant relationship and variation between their own attitudes and behaviours of Turkish, Libyan and Nigerian students according to their $m$ mothers' educational background. No significant difference was obtained between attitudes and behaviours towards environment according to educational background of the parents of teacher candidates in the research conducted by Kışoğlu [22]. This result matches up with the result of the research. In the same direction Gökçe et al. [23] detected no significant difference between the environmental attitude scores according to educational background of parents in the study they conducted.

The common effect was not found to be significant among the families' monthly income levels of Turkish, Libyan and Nigerian students as well as the attitudes and behaviours of students studying in Agriculture faculty of Northern Cyprus universities towards environment [wilkis lambda $\wedge=, 953, F=, 868, p=, 606$ $(p>, 05)]$. Again when Table 17 is examined, while there was generally a significant variation between family income levels and attitudes of all students $(\mathrm{p}=, 46 \mathrm{p}>, 05)$, no significant variation was found to among their behaviours. As a result of the Tukey HSD test which was made to find between what groups that difference was relating to the attitudes, it was observed that there is variation between TR, Libyan and Nigerian students who have an 
income between 1000 and 2000TL, and TR, Libyan and Nigerian students who have income between 2000 and 3000TL. When the distribution of this variation is examined according to income level, it was concluded that Nigerian students who have an income between 1000 and $2000(\bar{X}=58,82)$, Libyan students ( $\bar{X}=53,67)$ and TR students $(\bar{X}=47,50)$ have lower attitudes than those who have income levels between 2000 and 3000 for Nigerian ( $\bar{X}$ =60,59), Libyan, $(\bar{X}=59,77)$ and TR $(\bar{X}=60,67)$ students. Based on such results, it is obvious that as income level increases, the attitudes of both TR, Libyan and Nigerian students increase too. Considering the relation between monthly income of families and attitudes and behaviours towards environment, it can be seen in the study condcuted by Erdoğan [24] that the students that are in the middle and near-middle income group have more positive attitudes than those in low income group.

The common effect was not found to be significant between whether Turkish, Libyan and Nigerian students have received courses about the environment before as well as the attitudes and behaviours of students studying in Agriculture faculty of Northern Cyprus universities towards environment [wilkis lambda $\wedge=, 993$ $, F=, 513, p=, 726(p>, 05)]$. Again when Table 18 is examined, there was not found generally any significant variation between whether the students have received courses about the environment before and their attitudes $(\mathrm{p}=, 486, \mathrm{p}>, 05)$ and behaviours ( $\mathrm{p}=, 115, \mathrm{p}>, 05)$. Based on such findings, it is obvious that there is no significant relationship and variation between their own attitudes and behaviours of Turkish, Libyan and Nigerian students according to whether the students have received courses about the environment before. Ünal \& Dımışkı [25] revealed in the conducted study that courses of environmental sciences in schools are not enough and they cannot benefit from the course sufficiently in the answers of participants with regard to taking environmental courses by students. However, the course "Environment and Human" in the previous studies were evaluated as incomplete and insufficient both by students and by teachers $[26,27]$.

The common effect was not found to be significant between whether Turkish, Libyan and Nigerian students are a member of any organization about the environment as well as the attitudes and behaviours of students studying in Agriculture faculty of Northern Cyprus universities towards environment [wilkis lambda $\wedge=, 991, F=, 638, p=, 636(p>, 05)]$. Again when Table 19 is examined, there was not found generally any significant variation between whether the students are a member of any organization about the environment and their attitudes $(p=, 331, p>, 05)$ and behaviours $(p=, 523, p>, 05)$. Based on such findings, it is obvious that there is no significant relationship and variation between their own attitudes and behaviours of Turkish, Libyan and Nigerian students according to whether the students are a member of any organization about the environment. Yücel \& Morgil [28] and Görümlü [29] stated in their studies that they are not members of any organization regarding environment. They revealed that the students do not participate actively in any organisation regarding the environment in many researches conducted on university studen [30-32]. This result matches up with the result of the research.

The maximum score that could be taken from the participants as a result of environmental knowledge test is 18,00 . The score average of the participants taken from the knowledge test seems to be 10,57 . Taking into consideration this result, it can be seen that environmental consciousness of participants is average. We can see in Table 21 that only 6 of the questions asked are correct considering the answers given by the students for the environmental knowledge questions. Based on this result, we can say that students do not have enough knowledge about the environment. In some environmental researches that were conducted by academicians before, similar values to this result were obtained [33-36]. When the answers of university students for environmental knowledge are compared to the nationality, significant difference is obtained [37-40].

\section{References}

1. İncekara S, Tuna F (2010) Ortaöğretim Öğrencilerinin Çevresel Konularla Ilgili Bilgi Düzeylerinin Ölçülmesi: Çankırı Ili Örneği. Marmara Coğrafya Dergisi (22): 168-182.

2. Cevher Kalburan FN (2009) Çocuklar İçin Çevresel Tutum Ölçeği İle Yeni Paradigma Ölçeği'nin Geçerlik Güvenirlik Çalışması ve Çevre Eğitim Programının Etkisinin İncelenmesi. ayımlanmamış Doktora Tezi. Ankara:Gazi Üniversitesi.

3. Atasoy E, Ertürk H (2008) İlköğretim öğrencilerinin çevresel tutum ve çevre bilgisi üzerine bir alan araştırması. Erzincan Eğitim Fakültesi Dergisi 10(1): 105-122.

4. Yıldırım C, Bacanak A, Özsoy S (2012) Öğretmen adaylarının çevre sorunlarına karşı duyarlılıkları. Kastamonu Eğitim Dergisi 20(1): 121134.

5. Schultz PW (2002) Knowledge, Education, And Household Recycling: Examining The Knowledge-Deficit Model of Behavior Change. In Dietz T \& Stern P (Eds.), Education, Information, and Voluntary Measures in Environmental Protection. National Academy of Sciences, USA, pp. 6782.

6. Schultz PW (2002) Environmental Attitudes and Behaviors Across Cultures. In Lonner WJ, Dinnel DL, et al. (Eds.), OnLine Readings in Psychology and Culture, Western Washington University, Department of Psychology, Center for Cross-Cultural Research, USA.

7. Aydın F, Kaya H (2011) Secondary education students' thoughts and behaviours towards environment (Karabuk Sample-Turkey). American-Eurasian Journal of Agricultural \& Environmental 10(2): 248-256.

8. Atasoy E (2005) Çevre için eğitim: İlköğretim öğrencilerinin çevresel tutum ve çevre bilgisi üzerine bir çalışma. Yayımlanmamış doktora tezi. Uludağ Üniversitesi, Sosyal Bilimler Enstitüsü, Bursa, Turkey.

9. Alım M (2006) Avrupa Birliği Üyelik Sürecinde Türkiye'de Çevre ve İlköğretimde Çevre Eğitimi, Kastamonu Eğitim Dergisi 14(2): 599-616.

10. Budak B (2008) İlköğretim Kurumlarında Çevre Eğitiminin Yeri ve Uygulama Çalışmaları. Yayımlanmamış Yüksek Lisans Tezi, Ege Üniversitesi, İzmir, Turkey.

11. Bilgili S (2008) İlköğretim 7. Sınıf Fen ve Teknoloji Dersinde Çevre Konularının Öğretiminde, Yapılandırmacı Yaklașıma Dayalı Işbirlikli Öğrenmenin Öğrencilerin Erişine Etkisi. Yayımlanmamış Yüksek Lisans Tezi, Ankara: Gazi Üniversitesi, Turkey.

12. Şüyün B (2010) İlköğretim Öğrencilerinin Çevreye Yönelik Bilinç ve 
Algılamaları. Yayımlanmamıș Yüksek Lisans Tezi. İstanbul: Marmara Üniversitesi, Turkey.

13. Boyer E (1998) Commission on Educating Undergraduates in the Research University. Reinventing undergraduate education: A blueprint for America's research universities, NY, USA.

14. Probert EJ (2002) An Environmental Education Initiative with University Business Students. Applied Environmental Education and Communication 1: 53-59.

15. Büyüköztürk Ş (2002) Soyal Bilimler Için Veri Analizi El Kitabı. Ankara: Pagema Yayıncılık, Turkey.

16. Scheffe H (1959) The analysis of variance. New York: John Wiley press, USA.

17. Scheffe H (1953) A method of judging all contrasts in the analysis of variance. Biometrika 40(1-2): 87-104.

18. Karacaoğlu C, Çabuk B (2003) Üniversite Öğrencilerinin Çevre Duyarlılıklarının İncelenmesi. Ankara Üniversitesi Eğitim Bilimleri Fakültesi Dergisi cilt 36: 1-2.

19. Gündüz Ş, Dağlı G, Aslanova F (2015) Comparative Evaluation of the Environmental Consciousness Levels of High School Students in Northern Cyprus, Turkey and Azerbaijan. Anthropologist International Journal of Contenporary and Applied Studies of Man (KRE) 22(3): 622 635.

20. Makki Maha H, Abd-El-Khalick F, BouJaoude SL (2004) Secondary School Students' Environmental Knowledge and Attitudes. Proceedings of The Eight Annual Science and Math Teachers Conference 8: 164-166.

21. Teyfur E (2008) İlköğretim 4-7. Sınıf Öğrencilerinin Akademik Başarılarının ve Çevre Kulübü Çalıșmalarının Çevreye Yönelik tutumlarına Etkisinin Değerlendirilmesi 9: 1.

22. Kıșoğlu M (2009) Öğrenci merkezli öğretimin öğretmen adaylarının çevre okuryazarlığı düzeyine etkisinin araştırılması. Yayınlanmamış Doktora Tezi, Atatürk Üniversitesi, Erzurum, Turkey.

23. Gökçe N, Kaya E, Aktay S, Ozden M (2007) İlköğretim Öğrencilerinin Çevreyeyönelik Tutumları. Elementary Education Online 6(3): 452468.

24. Erdoğan N (2003) Çevre ve Ekoturizm, Ankara: Erk yayıncılık, Turkey.

25. Ünal S, Dımışkı E (1999) UNESCO-UNEP Himayesinde Çevre Eğitiminin Gelișimi ve Türkiye'de Ortaöğretimde Çevre Eğitimi. Hacettepe Üniversites Eğitim Fakültesi Dergisi 16(1): 142-154.

26. Uzun N, ve Sağlam N (2006) Orta öğretim öğrencileri çin çevresel tutum ölçeği geliştirme ve geçerliliği. Hacettepe Üniversitesi Eğitim Fakültesi Dergisi 30: 240-250.

27. Uzun N, ve Sağlam N (2006) Orta Öğretim Öğrencilerinin Çevre
Eğitim Programları Hakkındaki Görüşleri, Çalıșma VII. Ulusal Fen ve Matematik Eğitimi Kongresi'nde bildiri olarak sunulmuştur, Ankara, Turkey.

28. Yücel AS, Morgil İ (1999) Çevre Eğitiminin Geliştirilmesi. BAÜ Fen bilimleri Enstitüsü Dergisi, 1(1): 76-89.

29. Görümlü T (2003) Liselerde Çevreye Karşı Duyarlılığın Oluşmasında Çevre Eğitiminin Önemi, Gazi Üniversitesi Eğitim Bilimleri Enstitüsü, Ankara: Yüksek Lisans Tezi, Turkey.

30. Altın M (2001) Biyoloji Öğretmeni Adaylarında Çevre Eğitimi. Yayımlanmamış yüksek lisans tezi. Gazi Üniversitesi, Ankara, Turkey.

31. Çabuk B,Karacaoğlu C (2003) Üniversite Öğrencilerinin Çevre Duyarlılıklarının İncelenmesi. Ankara Üniversitesi Eğitim Bilimleri Fakültesi Dergisi 36(1-2): 189-198.

32. Özmen D, Çetinkaya AÇ, Nehir S (2005) Üniversite öğrencilerinin çevre sorunlarına yönelik tutumları. TSK Koruyucu Hekimlik Bülteni 4(6): 330-344.

33. Altınöz N (2010) Fen bilgisi öğretmen adaylarının çevre okuryazarlık düzeyleri. Yayımlanmamış yüksek lisans tezi. Sakarya Üniversitesi, Sakarya, Turkey.

34. Kibert NC (2000) An analysis of the correlations between the attitude, behavior, and knowledge components of environmental literacy in undergraduate university students. Unpublished Master Thesis, The Graduate School of The Unıversity of Florıda, Unıversity of Florida, USA.

35. Karatekin K (2011) Sosyal bilgiler öğretmen adaylarının çevre okuryazarlık düzeylerinin belirlenmesi, Yayımlanmamış Doktora Tezi, Ankara: Gazi Üniversitesi Eğitim Bilimleri Enstitüsü, Turkey.

36. Gündüz Ș, Aslanova F (2012) Determination of The Knowledge Levels And Attitudes of Azerbaijani University Students About Environmental Issues Educating in Azerbaijan And TRNd "Egitım Arastırmaları. Eurasian Journal of Educational Research 12(49A): 349-367.

37. Alım M (2000) Avrupa Birliği Üyelik Sürecinde Türkiye' de Çevre ve İlköğretimde Çevre Eğitimi. Kastamonu Eğitim Dergisi 14(2): 599-616.

38. Aydın F, Çepni O (2012) İlköğretim İkinci Kademe Öğrencilerinin Çevreye Yönelik Tutumlarının Bazı Değișkenler Açısından İncelenmesi (Karabük İli Örneği). Dicle Üniversitesi Ziya Gökalp Eğitim Fakültesi Dergisi 18: 189-207.

39. Kışalıoğlu M, Gürbüz H, Erkol M, Akar MS (2009) Liselerde Görev Yapan Öğretmenlerin Bilinçli Su Tüketimi Davranışlarının İncelenmesi.18. UlusalEğitim Bilimleri Kurultayında sunulan bildiri, Ege, Turkey.

40. Tahiroğlu M, Yıldırım T, Çetin T (2010) Değer Eğitimi Yöntemlerine Uygun Geliștirilen Cevre Eğitimi Etkinliğinin, Ilköğretim 7. Sınıf Öğrencilerinin Çevreye Ilişkin Tutumlarına Etkisi. Selçuk Üniversitesi Ahmet Keleşoğlu Eğitim Fakültesi Dergisi (30): 231-248.

\section{Your next submission with Juniper Publishers will reach you the below assets}

- Quality Editorial service

- Swift Peer Review

- Reprints availability

- E-prints Service

- Manuscript Podcast for convenient understanding

- Global attainment for your research

- Manuscript accessibility in different formats

( Pdf, E-pub, Full Text, Audio)

- Unceasing customer service

Track the below URL for one-step submission

https://juniperpublishers.com/online-submission.php 